\title{
Defending Identity and Diversity: the Potential of Cultural Anthropology for Reshaping Autism
}

\author{
Anatolii F. Gokh, Valerii V. Mineev \\ and Elena N. Viktoruk* \\ Krasnoyarsk State Pedagogical University \\ named after V.P. Astafyev \\ 89 Ada Lebedeva Str., Krasnoyarsk, 660049, Russia
}

Received 24.08.2018, received in revised form 22.11.2018, accepted 06.12.2018

This article focuses on the concept of autistic culture as a tool for providing autistic persons' integration into society and for empowering an autistic community. A multitude of people with autism were observed and asked questions to explore the relationship between their neurodivergents' collective identity and their ability to successfully integrate into society. Various pools of caregivers and professionals were also inquired to get an insight into their attitudes to the inclusion policy and to the upsurge of autistic culture. The survey performed in 2012-2018 revealed that autistic culture has started spreading into Siberian region, and a recognition of this phenomenon has already begun to progress in the city of Krasnoyarsk. Moreover, the research also showed that autistic people's awareness of own identity and diversity as cultural attributes, as a matter of fact, facilitated increased inclusion. Given these results and premises, a construct of autistic culture is elaborated and, respectively, a reshaping of the main signs of autism in terms of cultural anthropology is tried, with relevance of philosophical anthropology and phenomenology being highlighted. The objective and the scope of the article are consistent with the social policy designed for the diversity to be openly embraced and for people with special health needs as well as their families to enjoy a deep involvement.

Keywords: autistic culture, autistic community, cultural identity, social inclusion, diversity, the nature-culture divide.

Research area: culturology, social philosophy.

Citation: Gokh, A.F., Mineev, V.V., Viktoruk, E.N. (2018). Defending identity and diversity: the potential of cultural anthropology for reshaping autism. J. Sib. Fed. Univ. Humanit. soc. sci., 11(12), 1947-1961. DOI: 10.17516/1997-1370-0368.

(c) Siberian Federal University. All rights reserved

* Corresponding author E-mail address: an_goh@mail.ru; vvmineyev@mail.ru; eviktoruk@yandex.ru

This work is licensed under a Creative Commons Attribution-NonCommercial 4.0 International License (CC BY-NC 4.0). 


\section{Introduction}

Numerous people with special health needs (SHN), in particular, individuals diagnosed with autism spectrum disorder (ASD) have been growing into a crucial social constituency. This large segment of population encompasses not only persons with SHN, but also their close social environment, families and caregivers. The funding of rehabilitation institutions is seen economically unsustainable in contrast with the true inclusion which enables people with SHN to actively participate in social life. A person with autism needs a community-based habilitation. Medical rehabilitation, let alone correction, may not be appropriate. Rare cases are said to have recovered from the condition. Meantime, bureaucracy, whatever domain it resides in, is resisting to a change and doesn't appear to be reliably under the civilian control. Besides, frequent abuses and discrimination in hiring or dismissal on the ground of impairments (disability) are not conducive to a solution of the deadlock situation.

For the present, a considerable part of society remains, however, unwilling to accept the underlying principle to building inclusive community: Nothing about us without us. But much moves committed professionals and crusaders to re-imagine what it means to be an autistic and what it means to support autistic people who together with their folks may implement their own management strategies. The tenets of humanism and tolerance strengthening, any apparent or implicit disrespect of autistic community's vision and position on this or that question is becoming increasingly anachronistic. In addition, instrumental, technocratic approach detached from the axiological dimensions of a human being, does not meet the imperatives of contemporary, as it were, non-classical science.

People diagnosed with ASD are declared to have difficulties with social interaction. A system of conceptions expressed in symbols by means of which people communicate has been identified as culture by Clifford Geertz following Max Weber's and some phenomenologists' key ideas (Geertz, 1973). That is why reshaping the phenomenon of autism in the prospect of cultural anthropology appears to be fairly promising. There is much to build on. Anyway, autistic culture in close conjunction with which both an autistic person and autistic community develop is to be considered as a contributive social construct, a tool for providing autistic persons' integration into society and for empowering an autistic community. To improve interaction with autistic people, our neurotypical society, perhaps, needs some social and cultural interventions rather than medical ones. 


\section{Theoretical Framework}

Today not only ethnic communities or cultural and historical regions, but also groups of a different kind - various organizations, corporations, and even individuals are held to be a target of cultural anthropology. The subject area of this scientific discipline can be initially reconstructed in the light of the major ontological oppositions involving culture. The range of the matches covers nature, society, man (personality), and technology. Also cultures are interacting among themselves. Various currents of thought (partly complementary, partly mutually exclusive) in the field of anthropology are established depending upon how the role of a certain pole in an opposition is viewed. The nature-culture divide is assumed to be of the greatest importance. Also some element of the cultural or natural universe - science, art, religion, sign, structure, life, death - may be granted a special significance.

Since ancient times, culture was constituted in opposition to nature. In general, the clash between two entities remains significant for today's science, although tends to be interpreted in somewhat different ways. The old dichotomies (nature versus nurture or necessity versus freedom) have been replaced by an awareness of complexity of the interplay. However, the divide continues to provide a foundation of anthropology, taking the gender roles theories, the theory of gene-cultural co-evolution (the dual inheritance theory) or the cultural selection theory as examples. Sometimes social and cultural tendencies are couched as manifestations of human nature. On the other hand, the nature itself may be treated as a cultural and social construct. So, we come to the crucial point of the theoretical framework our research is based upon.

Both culture and, as it were, nature including such natural phenomenon as a disease, a mental disorder, or even death have to be thought of as social constructs, following the richest philosophical traditions a galaxy of great thinkers belong to (Foucault, 1976, Goffman, 1961, Geertz, 1973). According to Geertz, who entertained intimately humane, interpretative approach and sought to combine American cultural anthropology with European phenomenology, all texts in the social sciences are constructions, fictions; it doesn't diminish their benefits though. Our suggestion is that the concepts, in a measure, conventions of autism, autistic culture, autistic self-identity etc. are intended to serve as a tool for constructing, that is thinking and developing, social reality as well as for interaction and communication, not for exclusion.

The concept is an elementary cognitive unit, a bundle of ideas, sense-contents, or intellectual experiences. It is some mental entity that allows one to interpret a phenomenon depending on personal and social experience. Without going into the fine 
points of well-known debates, we just stress that a concept (der Konzept) in this special sense of word is not tantamount to a formal logical concept, a product of generalization, or a notion (der Begriff). It is an implement of interdisciplinary research, moreover, an innovative message that arranges people's joint activity; an interface between a word and reality. Using a concept of culture helps to comprehend all the totality of an autistic's life: the variety of things and ideas created by autistic people (perhaps, by others for them), the tapestry of human qualities (inherent in the personality), the coherence of seemingly unlike actions giving expression to inner values, and in the long run, the ensemble of such manifestations of structure maintaining integrity as language, communication forms, institutions, movements...

Any concept is a channel of conveying culture in the world of psychic experiences and, at the same time, a tool our mentality influences cultural codes. The conceptualization of autistic mentality - that is a bundle of particular personal perceptional and cognitive styles - as a certain facet of a special culture paves the way to a dialogue between different agents building a coordinated world picture and expanding the frontiers of intersubjectivity, i.e. mutual understanding. Thus, a cultural and simultaneously cognitive basis for persons with ASD to be fully integrated in society, moreover, to be involved in the enterprise of building scientific and philosophical knowledge would be created.

As to a relevant theoretical perspective for the study, some set of assumptions generally inspired by Lebensphilosophie, Husserl's phenomenology, and finally philosophical anthropology seems to be proper, since this approach offers an explorer the theoretical underpinning and research strategies to bridge the gap between the inner world of the man and the world of cultural symbols shared by a large social group. A distinguishing feature of philosophical anthropology, in contrast with existentialism aimed, too, toward the solution of seemingly the same issues, is the willingness and the readiness to heavily rely on the data obtained from specific fields of science, such as biology, medicine, psychology, and sociology. Therefore, on the one hand, classical studies by H. Plessner, A. Gehlen, M. Landmann, and their numerous contemporaries preparing a transition from anthropological philosophy to cultural anthropology deserve a careful attention (Landmann, 1979). On the other hand, the mindsets and ideas of contemporary researchers working in the mainstream of the paradigm of neurodiversity (Jaarsma and Welin, 2011) as well as the paradigm of autistic's own perceptual and cognitive style (Williams, 1992, Happé, 1999, Bogdashina, 2010) are the best fit for the objectives of this study. 
Cultural anthropology is neither a branch, nor a current, nor a kind of anthropology or culturology. A comparison of these concepts is an extremely difficult challenge. In the scope of this study, it would be correct to confine to a broad understanding of cultural anthropology, taking into account Rothacker's thesis that any kind of social community has its own type of culture. And autistic community is not an exception. It is worth recalling that the foundations of the integrative theory of man have been laid by Immanuel Kant, not by Max Scheler. Kant divided this discipline into physiological anthropology and pragmatic one. The physiological anthropology concerns the investigation of what nature makes of the human being, and the pragmatic one relates to what the human being as a free-acting being makes of himself or can and should make of himself (Kant, 2006). It was Kant who accented the role of culture in this process of man's self-creation, self-invention.

A problem, once it is truly humanitarian, is usually related to human suffering that is to local conflicts or social antagonism in general, to the diversity, therefore to detachment, exclusion and lack of mutual understanding. Thus, achieving the ultimate goal of cultural anthropology envisages integration of an individual or a group into society to restore harmony between man and society as well as between man and nature.

\section{Materials and Methods}

A large body of scholarly writings and other sources of information on cultural dimensions of autism were analyzed. Autistic people were observed and various pools of respondents were inquired to comprehensively explore the potential of the culture concept for providing autistic persons' integration into society.

This investigation relied mostly on qualitative data collection methods, rather than quantitative research. Content analysis (various techniques), an unstructured conversation, a highly structured interview, in-depth interview, a participant observation, intent-analysis, case-study and focus-groups study as well as elements of comparative analysis and longitudinal analysis were employed. We would also like to put a special focus on our recourse to interpretative methods inherent to medical anthropology as a subfield of cultural anthropology (Good, 1996).

\section{Results and Discussion}

The results obtained are to be divided into three sections.

The first segment of the data is aimed at throwing light on autistic people's understanding of their identity and diversity (difference, unlikeness). This interest is 
quite reasonable because any particular culture is hardly possible without a piece of self-awareness.

The second portion of the data promotes a shift to external perspective, with parents', professionals' and other neurotypicals' opinions being taken into consideration. This point is, too, fully understandable, because cultures interact with each other. Moreover, cultural identity as a feeling of belonging to some group may be greatly influenced by social network, may arise as a backlash or in response to labeling etc.

The third segment of the gained knowledge relates to the matter of introducing the concept of autistic culture.

\section{People with Autism}

Within the period from July 2012 to May 2018, in the premises of social homestead Dobraya (Russian: Добрая - "kind, good") as well as other municipal social services centers, under the aegis of Krasnoyarsk regional public organization Svet Nadezhdy (Russian: Свет надежды - "light of hope"), a multitude of people with autism were looked after and asked questions to explore the relationship between neurodivergents' identity and the ability to integrate into society.

By the end of the period, the number of persons surveyed had exceeded 200. The whole autism spectrum (ASD) - including autism, atypical autism (PDD-NOS), Asperger syndrome (AS), high-functioning autism (HF), and other related conditions was presented. As regards years of age, genders, patterns of behavior, and condition severity, the pool was intended to be as miscellaneous as possible. So, the age of participants ranged from 4 to 30 . Under the roof of homestead, the guests shared in sports events, certain adventure games, concert engagements, tea parties, and other activities, with duration of a visit reaching, sometimes, 8 hours (from 13 p.m. to 21 p.m.) and the frequency of visits averaging around one appointment a month. Up to 100 visitors could come to the homestead at a time, on rare occasions though.

For a long time, year over year, an autistic person had been invited to steadily develop an own world outlook. Everyone had been offered a lot of age-appropriate questions advancing to increasingly difficult topics to map out his or her long-term scenario. What can you say about yesterday's cartoon? What is a family? What is love? What would you like to become in the future? What do you have to do to make your wishes come true?

First manifestations of identity could be seen in individuals at the age of 12-14 years. For instance, a child making excuses used to say, I am an autie after all. Yet, 
awareness of own identity and diversity never seemed to be accomplished until the age of 30. An adult would say, I always thought that something was different with me. As a matter of fact, the meaning could be expressed quite otherwise. E.g., I always thought that something was wrong with me. However, a sophisticated intent-analysis proved that Was wrong should be interpreted as Was different. This is where we come to some important remarks.

In compliance with the general requirements and conventional standards for the care and/or treatment of autistics, a caregiver shouldn't lay stress upon difference. That is why the researchers, to prevent impairments, were obliged to confine themselves to asking indirect questions, and to avoid enquiring about the awareness of diversity openly. In addition, an interviewer should take care not to impose terms and meanings. Sometimes a person-first language, to eschew conscious or subconscious dehumanization, was employed. An autie is anything but a victim or a patient. Most of people with autism don't consider their condition a disease. Hence, there are certain difficulties with picking up a generic term to conceptualize their self-identity. In this regard, much important results were obtained in homestead Dobraya. As to modest purposes of this article, we can afford only a few statements.

First of all, the Homestead autistic people's vision of own diversity has been shown to be consistent with the features of cultural identity. We believe nearly 80 of the 200 person pool $(\approx 40 \%)$ demonstrated, more or less, these features. The severity of the other persons' condition didn't allow us to take into account their records. Only a few had an excellent verbal repertoire. The figure of $40 \%$ can thus be found notably high. Besides, adults including initially children who had time to reach adulthood during the study period were about 50 of the $200(\approx 25 \%)$. Only 8 of 50 (16\% of adults) belonged to the cohort of high-functioning autistics, savants in the broad sense of the word. However, all 8 respondents $(100 \%)$ decisively advocated for promoting the message of autistic culture, for "telling us who we are". From our point of view, they provided a global voice for the autistic population and can be viewed as sufficiently reliable agents of its interests, though we would refrain from discussing validity and representativeness of the savants' opinions in terms of sociology.

Second, the research revealed that the auties endeavored to participate fully in social activities. They succeeded in mastering both socially important specialties (cooking, plant growing) and creative ones (music, fine arts). Teamwork and versatility occurred, on a journey of self-discovery. Their awareness of own diversity didn't impede social interactions, rather, facilitated these interactions greatly, but how? Observations and 
analysis have led us to a conclusion that consciousness of community helped people with autism to communicate both with each other and with neurotypicals. To begin with, in the composition of the autistic community consciousness, several components having certain implications of cultural identity are easy to differentiate:

1) cognitive (mental), communicational, linguistic, and symbolic cohesion;

2) feeling of universal oneness of autistic population;

3) group conscience (social awareness, social responsibility);

4) awareness of deep commonality of long-term interests; unity of destiny;

5) sense of joint purpose, therefore mindset to transformation, personal growth.

Components 4 (long-term interests) and 5 (joint purpose) are of particular importance for the positive effect of autistic cultural identity to be explained because it is impairments in social interaction and communication as well as the restricted interests and repetitive behavior that are considered essential symptoms of autism spectrum disorder. The point is, auties' awareness of the cultural unity develops from meeting challenges for survival in the hostile environment through strengthening relationships within the community, through friendship, support and personal growth to expansion of internal cohesion to a larger society as a seat of the community. One consents to engage in society for the good of the community.

To crown it all, people with autism, perhaps, perceive universal human values (justice, friendship, freedom) in a special way, to a degree. Besides, the community may just as well cherish own distinct qualities and virtues. The stronger the unity of shared accomplishments is, the easier it is to jointly integrate. This hypothesis, however, requires verification. Be that as it may, the assumption of autistic culture appears to be much more fruitful than mere behavioral or pragmatically situational explanations foreclosing paths to recognition of an autistic community and its developmental capabilities.

\section{Caregivers and professionals}

Within the same period from July 2012 to May 2018, in the premises of social homestead Dobraya, multiple caregivers and professionals were inquired to explore their attitude to the policy of inclusion, and to the idea of autistic culture. The total of persons surveyed has exceeded 500. The pool comprised parents, family friends, social workers, teachers, health workers, and general practitioners (apart from treating experts). A lot of data still requires processing and correct interpretation; even so, much important results obtained clearly indicate that Siberian society has started moving 
from awareness of autism to acceptance of the latter, and from formal engagement to deep involvement. Not all our interlocutors have decided on a position (their statements weren't taken into account). And many had been changing their minds in the study period. According to our rough estimates, the proportion of the respondents encouraging inclusion differed among various groups as follows:

Family friends $\quad-95 \%$ or more;

Parents $\quad-50$ to $90 \%$ (see clarification of the variance below);

Social workers $\quad-60$ to $65 \%$;

Teachers $\quad-25$ to $30 \%$;

Health workers $\quad-10 \%$ or less.

As a rule, medics are facing the most severe cases of the disorder. The low levels of confidence in inclusion project therefore were established.

Social workers, unlike teachers, have an access to a more complete portrait of the persons under their care and understand the meaning and patterns of inclusion much broader. They know potential of the people with autism and consequently are more sanguine about inclusion. Besides, macro-work involves not only interaction with an individual or a group, but also activities within social policy.

Family friends don't separate an autie from his or her family and interact with the home as with a single whole. It looks like a first stage of inclusion. Family friends, an inner circle, are at the interface between an autistic family and a larger world. They all are crusaders. With this in mind, high rate of votes in favor of inclusion isn't surprising.

Due to recurrent ambivalence in responses, quantitative data for parents were the hardest to capture. The vast majority of parents welcomed the idea of inclusion, but nearly half of them were not certain about feasibility or practicability of inclusion. Curiously enough, parents normally assigned a key role in deployment of inclusion culture to the school, whereas teachers had a broader look at the subject.

As to the autistic culture, only $5 \%$ of the pool surveyed clearly understood the true meaning of the concept. However, more than $90 \%$ of this small group vigorously accepted the message. About $10 \%$ of the "understanding bunch" rejected, on various grounds, development of autistic culture.

In April 2018, a conference entitled The Inclusion Week at the City was held by Krasnoyarsk Main Department of Education in conjunction with Krasnoyarsk State Pedagogical University. A focus group of 50 persons facing autism by virtue of their professional activities was inquired. On the one hand, 24 of 50 respondents (48\%) believed that inclusion culture had been already created in the sphere of education in 
the city of Krasnoyarsk. On the other hand, 27 of 50 respondents (54\%) linked the spread of autistic culture in the region precisely to the deployment of inclusion culture. The focus group participants also pointed out unanimously that the process had been influenced or even induced by the West. Yet, one should keep in clever mind that autistic community is an international minority dispersed throughout the world, and this factor, particularly in the setting of the global village, will persist in leaving a deep imprint on possible strategies for social planning and management.

Although inclusive culture and autistic culture are overlapping they are by no means the same thing. Not all proponents of inclusion deployment are advocating for development of autistic culture.

\section{The Autistic Culture Concept}

The experience gained thus far allows us to suggest some working definition.

Autistic culture can be defined as a social construct conveying the unity of mental, linguistic, symbolical, communicational, behavioral, societal and some other socially transmitted characteristics of people who belong to the autism spectrum; a construct indicating common values, symbols, and rules as well as meaningful material objects, human qualities, and social practices to sustain an autistic community and to provide a personal growth of an individual with autism. Autistic culture involves a measure of cultural identity and, respectively, certain attitude to others.

The investigation of the autism phenomenon provides a greater insight into the mystery of the interplay between biological factors of evolution and socio-cultural ones, into the dual nature of the mind. Autistic's perception of the world, like any perception, has - beyond any doubt - specific biological grounds which should not be addressed in a manner of pathology, but, first and foremost, as a result of the preceding genetic and cultural co-evolution.

Analysis of medical, psychological and pedagogical discourses in the space of which autism is construed as a subject of scientific research has shown that the main symptoms of autism can be fruitfully reshaped in terms of cultural anthropology. After all, ritual behavior, compulsive behavior, resistance to change, detachment, and many other signs of a person with autism can be recognized as cultural dominants, moreover, as a means of cultural resistance. Aggression, fright, peculiar reactions to external stimuli etc. are, to a degree, socially determined phenomena. Detachment and withdrawal would pass as a life style. Of course, the feeling of loneliness, this lifelong sense of disconnection, in childhood and in older age, is an unpleasant experience. And 
it is the enormous transforming power of a special cultural identity that is designed to help an autie to be alone without being lonely or to enjoy a new avenue for social connections. The sense of difference persisting since its nascence in early life often has a want of cultural justification for the diversity to be openly embraced.

Language, one of the essential cultural manifestations, is at the same time a thing deeply rooted in biological nature of a human being. Fearfully and wonderfully made, language is not only a means of maintaining culture, but also a fundamental condition for its emergence. Communication impairments relating to speech, visual perception or auditory perception are well known to cause new sign systems. Similar effects of communication difficulties are possible to detect in some cases of autism spectrum disorder. In addition, today's rapid pace of communication development in children with autism coincides, not accidentally, with the uprising of autistic communities, social movements, advocacy and self-advocacy, confirming actuality of autistic cultural identity.

Recognition of the fact that autism is culturally loaded, i.e. strongly grounded in conventional assumptions and biases, in no respect implies denying biomedical background of this phenomenon. And it does not remove from the agenda the tough issue of the clash between two realms in man, either. It is this clash that compels some, for example, Gehlen, to talk about man as an animal, and others, in particular Landmann, to ignore the significance of the biological background.

However, behind the opposition of the biology and culture there is also another tension, namely antithesis of a priori knowledge and empirical learning. What is the difference between a man and an animal? What is the norm as opposed to the disease? What it may mean - progress, creativity, rationality, freedom? One can try to answer any of these questions from the perspective of the available empirical evidence. Then the threat of relativism leading to the loss of the humanity ideal would increase. Once metaphysical or phenomenological approaches are tried, there would likely be a departure from reality and an indulgence in futile intellectual constructs.

In dealing with these dilemmas, Landmann, for instance, quite consistently rejects the biological evolutionary explanation of the human situation (Landmann, 1979). In addition, he is very close to the Bergsonian idea of creative evolution: multiple kinds of life have equal value. Cultures should not be ranged in a hierarchy. Each culture, each living thing, each human faculty has its worth, an intrinsic value. According to Landmann, development does not always go vertically, higher or deeper, but very often flows horizontally (Landmann, 1979). Such typological approach, in contrast to 
a trivial biological evolutionism saves both the worth of the later and the worth of the earlier.

It is owing to a colossal humanistic content together with phenomenology intuition allowing a privileged access to private worlds, to personal perceiving and cognitive styles, that philosophical anthropology appears to be useful for rethinking the phenomenon of autism. After all, the chief trouble is that autism is seen as a mysterious disease, therefore, a danger to people. Many want autism spectrum to be medically eradicated. They wish the auties weren't in society. Such expectations are, in some respects, consonant with the theory and practice of xenophobia.

Over the past fifty years, medical system of coercion and oppression had been seriously challenged and affected drastically by ideological and institutional changes launched by Ronald Laing, Thomas Szasz, Erving Goffman, Franco Bazaglia and their numerous followers (Bazaglia, 1965; Raschid, 2005). Jean Baudrillard discovered a global import of social inclusion (Baudrillard, 1993). A turn to the oeuvre of Michel Foucault, of course, also contributes greatly to changing stereotypes of autism. Foucault's history of medicine clearly demonstrates how a disease is couched within the medical discourse (Foucault, 1976). But to this day, the process of establishing inclusion culture is far from finished (Viktoruk and Mineyev, 2016). Biased judgments about mental inferiority, lack of empathy, and inability to successfully communicate all these labels, as a matter of fact, boils down to justification for the dominance of those who have no desire to hear the Other. On the contrary, due to the status of an autistic culture representative, a person is given an opportunity to be exactly who he or she is. The autistic culture construct is intended to overcome the exclusion of people on the basis of their level of functionality, and to arrange a dialogue between the autistic community, the "community around autism" (parents, specialists) and, finally, society as a whole. That would be inclusion.

\section{Conclusions}

The concept of autistic culture, as shown by the study, seems to be a fairly reliable pivot for the full integration of persons with special health needs into society, for policies of supporting inclusive practices in today's Russia, and last but not least for engaging some of the neurodivergents in science activities.

Our claim is that autistic culture has started spreading into Siberian region and, respectively, a recognition of this controversial notion, albeit somewhat belatedly, has begun to progress in the city of Krasnoyarsk. The research developed within as well 
as outside social homestead Dobraya (Krasnoyarsk) revealed that people with autism were striving for increased participation in social life. Moreover, it was awareness of their own identity and diversity as cultural attributes that facilitated their integration by helping them communicate both with each other and with "cousins" or neurotypicals. However, this experience requires further scrutiny.

A close perusal of a broad array of scientific and other complementary sources of information gives rise to yet another couple of statements. The catchphrase of autistic culture has received widespread publicity, but still lacks comprehensive philosophical justification and is excessively politicized. The idea is known to have divided community into camps - neurodiversity movement and pro-cure movement. Hence, a balanced approach should be found to avoid both extremes. Since causes of the disorders, and also diagnostic methods are culturally informed, medical anthropology devotes, indeed, considerable space to such matters as the ways autism is viewed, uneven distribution of autism among different nations (Montanez, 2016), the role of lifestyle in genesis of the disorder (Daley, 2002), local health models, and in the long run the shaping of autism as a cultural construct (Solomon, 2010). Nevertheless, to bridge the gap between the stances, autism is to be conceived within a much broader cluster of cultural anthropology, which may allow the explorers to span both personal experience of autistic people constructing the world differently (Grinker, 2008), and the universally shared values and symbols. Also we would set great store by the construction of autistic culture for the latter is able to decrease tension between nature and culture as well as between norm and pathology, to extend a range of culture identifiers, and to have a beneficial effect on considering a lot of other issues.

\section{References}

Bogdashina, O. (2010). Autism and Edges of the Known World \& Sensitivities, Language and Constructed Reality. London and Philadelphia, Jessica Kingsley Publishhers. 224 p.

Bazaglia, F. (1965). Silence in the Dialogue with the Psychotic. In Journal of Existentialism, 6 (21), 99-102.

Baudrillard, J. (1993). Symbolic Exchange and Death. London, Sage Publications. 254 p.

Daley, T. (2002). The Need for Cross-cultural Research on the Pervasive Development Disorders. In Transcultural Psychiatry, 39 (4), 531-550.

Foucault, M. (1976). The Birth of the Clinic. London, Tavistock Publications Ltd. $217 \mathrm{p}$. 
Geertz, C.J. (1973). The Interpretation of Cultures. N.Y., Basic Books. 470 p.

Goffman, E. (1961). Asylums: Essays on the Social Situation of Mental Patients and Other Inmates. New York, Doubleday. XIV, 386 p.

Good, B.J. (1996). Medicine, Rationality and Experience. An Anthropological Perspective. Cambridge, Cambridge University Press. 262 p.

Grinker, R.R. Unstrange Minds: Remapping the World of Autism. N.Y, Basic Books, 2008. IX, 340 p.

Happé, F. (1999). Understanding Assets and Deficits in Autism: Why Success Is More Interesting than Failure. In Psychologist, 12 (11), 540-547.

Jaarsma, P, Welin, S. (2011). Autism as a Natural Human Variation: Reflections on the Claims of the Neurodiversity Movement. In Health Care Anal., 20 (1), 20-30.

Kant, I. (2006). Anthropology from a Pragmatic Point of View. Cambridge etc., Cambridge Univ. Press, 2006. 240 p.

Landmann, M. (1979). Fundamental Anthropologic. Bonn, Bouvier. 309 p.

Montanez, S. (2016). An Anthropological Perspective on the Prevalence of Autism. In Sociology and Anthropology, 4 (5), 315-319.

Raschid, S., Ed. (2005). R.D. Laing: Contemporary Perspectives. London, Free Association Books. 325 p.

Rejeb, A., Namouchi, I. (2010). Genetic and socio-anthropological regards in Infantile Autism. In International Journal of Modern Anthropology, 1 (3), 98-114.

Solomon, O. (2010). Sense and the Senses: Anthropology and the Study of Autism, Annual Review of Anthropology, 39 (1), 241-259.

Viktoruk, E.N., Mineyev, V.V. (2016). Actualizing the Methodological Potential of Michel Foucault Philosophy in Praxis of a Physician, an Educator and a Psychologist. In Siberian Journal of Special Education, 1-2 (16-17), 40-46.

Williams, D. (1992). Nobody Nowhere: The Remarkable Autobiography of an Autistic Girl. London, Doubleday. 


\title{
В поддержку идентичности и многообразия: потенциал культурной антропологии для реконструкции аутизма
}

\author{
А.Ф. Гох, В.В. Минеев, Е.Н. Викторук \\ Красноярский государственный педагогический \\ университет им. В.П. Астафьева \\ Россия, 660049, Красноярск, ул. Ады Лебедевой, 89
}

В статье основное внимание уделяется концепту аутичной культуры как инструменту обеспечения интеграции аутистов в общество и расширения прав и возможностей аутичного сообщества. С иелью исследования взаимосвязи между коллективной идентичностью нейродивергентов и их способностью успешно интегрироваться в общество проводились наблюдения и опросы множества людей с аутизмом. Разнообразные группы сопроводителей и профессионалов также были опромены, с тем чтобы получить ясное представление об их отношении к политике инклюзии и к прогрессу аутичной культуры. Обследование, проведенное в 2012-2018 годах, показало, что аутичная культура начала распространяться в Сибирский регион, и признание этого явления уже стало набирать силу в Красноярске. Более того, исследование также показало, что осознание аутистами своей самобытности как культурной характеристики, на самом деле, способствовало улучшению качества инклюзии. С учетом этих результатов и предпосылок разрабатывается концепт аутичной культуры и, соответственно, предпринимается попытка реконструировать основные признаки аутизма в терминах культурной антропологии; при этом обращается особое внимание на релевантность философской антропологии и феноменологии. Цели исследования и область применения его результатов отвечают социальной политике, направленной на то, чтобы многообразие было принято в полной мере, а люди с особыми потребностями здоровья, как и их семьи, получили бы возможность полноченного участия в жизни общества.

Ключевые слова: аутичная культура, аутичное сообщество, культурная идентичность, инклюзия, многообразие, оппозиция природы и культуры.

Научная специальность: 24.00.00 - культурология, 09.00.11 - социальная философия. 